\title{
グラベルパイルによる水平地盤の二次液状化防止について

\author{
ON PREVENTING SECONDARY LIQUEFACTION OF LEVEL GROUND \\ USING GRAVEL PILES
}

\author{
田中幸久*・国生剛治**・江刺靖行*** ・ 松井家孝**** \\ Yukihisa TANAKA, Takaji KOKUSHŌ, Yasuyuki ESASHI and Iyetaka MATSUI
}

\begin{abstract}
In this research, upward seepage flow tests and analysis have been performed for the model ground with or without a sigle pile, in order to investigate the effects of gravel piles on the stability of surface soil against so-called secondary liquefaction. The results calculated by analytical procedure are in good agreement with the experimental results for every case tested in this research. Finally, authors estimated the effects of gravel piles against secondary liquefaction by calculating bearing capacity of the improved ground considering excess pore pressure in the ground.
\end{abstract}

\section{1.はじめに}

飽和砂地盤の地震時液状化の問題は, 土質工学上の重 要な問題として取り上げられてきた.そして，地震を受 けた飽和砂地盤が液状化に至るまでのメカニズムの解明 と対象とする地盤が設計地震入力に対して液状化するか 否かの判定方法の確立に大きな労力が払われてきた。一 方, 具体的な液状化対策となるとサンドコンパクション パイル工法に代表される締固めによる地盤改良工法が現 在に至るまで主流である. しかし，近年になって締固め 工法とは改良原理の異なる液状化対策工法が提案される に至っている. そのうちの 1 つに, 砅のように砂よりも 大きな透水性を有する材料より成る柱を排水工として地 中に設置することによって, 地震時の砂層内の過剩間隙 水圧の上昇を抑えて液状化を防止しようとするものがあ

* 正会員 工修 (財) 電力中央研究所土木研究所立地部 土質基礎研究室担当研究員 ( ( 270-11 我孫子市我孫子 1646)

** 正会員 工博 (財) 電力中央研究所研究開発本部原子 力部立地技術担当 (課長)

( ( 100 千代田区大手町 1-6-1)

*** 正会員 工博 (財) 電力中央研究所土木研究所耐震構 造部長 （テ270-11 我孫子市我孫子 1646)

**** 正会員 (財) 電力中央研究所土木研究所立地部調查役 (同上)
る. 通常，このような目的で設置される碩の柱をグラべ ルドレーンまたは砕石ドレーンとよぶことが多いが, 近 年, 柱以外の形体で用いられることもあるので, 本報告 においては特に円柱として用いられるものに関しては， グラベルパイルとよぶことにしたことをあらかじめ断っ ておく、既報において著者らは, 地震動に伴う繰り返し せん断による過剩間隙水圧の蓄積速度を小さくする目的 でグラベルパイルを設置する際の簡易設計式について述 べた1). 本論文においては，いわゆる二次液状化の防止 効果について述べる.

地震動終了時に地盤内に残留した過剩間隙水圧は, そ の後その空間分布を変えながらしだいに逸散してゆく. 構造物の沈下や地下構造物の浮上で代表される液状化に よる被害の多くは,この逸散過程で起こっている. 石原 ${ }^{2)}$ は, 相対密度が深さ方向に一様で, 地下水位が地表面下 $1 \mathrm{~m}$ にある水平砂地盤を想定して, 水平地震動による過 剩間隙水王の蓄積量を計算によって求めている. その結 果から, 深さ 5 - $10 \mathrm{~m}$ 程度の深度で間隙水圧が特に上 昇しやすいことを指摘している．また，すでに吉見 ${ }^{3)}$ が 指摘しているようにシード (Seed, H. B. ) ら ${ }^{4)}$ が行っ た新潟地震において液状化した代表的な地盤に対する液 状化解析の結果をみても最初に液状化するのは深さ 4.5 $\mathrm{m} \sim 12 \mathrm{~m}$ の砂層である.こうしたことを考えると, 地 
震動継続中には液状化しなかった地表面近くの地層も， 過剩間隙水圧の逸散過程において, 地震動継続中に液状 化した下部砂層からの上向き浸透流により間隙水圧が上 昇し液状化する可能性がある，本論文では，この現象を 水平地盤における「二次液状化」とよぶことにする.こ れに対して, 地震時の繰り返しせん断により上昇した過 剰間隙水圧によりほぼ非排水条件下で生じる液状化を 『一次液状化】とよぶことにする，一方，地下水面が地 表面に一致している場合であっても，地表面付近の液状 化強度が大きく,深部の液状化強度が小さい場合には, 二 次液状化が生じる可能性がある，このことは，言い換え ると二次液状化さえ防ぐことができれば，地表面近くの 砂層のみを締め固めることにより，地表面上の構造物ま たは地表面付近の地中構造物の液状化に対する安全性 は，容易に高められることを意味している。こうした方 法は，下部砂層の液状化安全率が非常に小さく，グラべ ルパイルによる一次液状化防止が困難である場合の地盤 の支持力確保の手段としては有効であると考えられる.

吉見ら ${ }^{5)}$ は，非改良地盤に対して 2 層地盤の液状化解 析を行い，上部砂層の透水性を高めることが，本論文で いう「二次液状化」の防止に効果があると述べている. さらに，この解析結果をもとにして，粗粒材料を用いた 締固め杭で表層付近を締め固めることは, 液状化の防止 に効果があると述べている.

このように，グラベルパイルが二次液状化防止に対し て効果があることはすでに指摘されているところである が効果の定量的な評価となるといまだに行われていない のが現状である．本報告では，グラベルパイルの二次液 状化に対する効果を数値解析と実験により確認するとと もに解析的な手法により，二次液状化防止効果を定量的 に評価することを試みた。

\section{2. 改良地盤の二次液状化防止効果に対する数 值解析的な検討}

本章では，地震時における間隙水圧の発生・消散を考 慮することができる数值解析プログラム GADFLEA を用いて，グラベルパイルによる改良地盤の二次液状化 防止効果に対する数値解析的な検討を行う.

解析する地盤は, 図一1 に示すモデル 1 モデル 4 の 4 種類である. モデル 1 は非改良地盤であり，モデル 2 〜モデル 4 は改良地盤である. モデル 2, モデル 3 は, グラベルパイルを上部砂層にのみ設置した場合であり， モデル 2 の場合には，グラベルパイルの底が不透水であ る. モデル 4 は，グラベルパイルを下部砂層にまで設置 した場合である.いずれの場合にもグラベルパイルの透 水性は，砂の透水性に比べて十分大きいとしている．な お，実際の計算においてはグラベルパイルの側面は排水
面 $(u=0)$ としている. また, 解析に用いたパラメーター の大きさを表一1 に示す.

図一2 に改良地盤内，非改良地盤内の過剩間隙水圧の 経時変化を示す。ただし，改良地盤内の過剩間隙水圧の 值は， $r=r_{e}$ におけるものである．ここで $r_{e}$ は，有効 円の半径を表わす。図一2によれば，非改良地盤の上部 砂層の過剰間隙水圧が液状化近くまで上昇しているのに

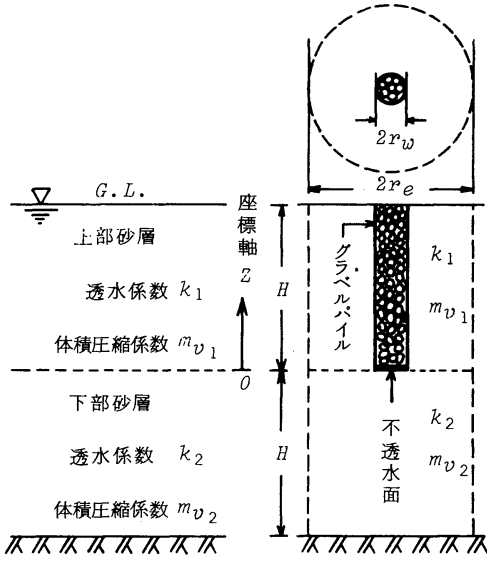

(a) モ ディ 1

(b) モデル2
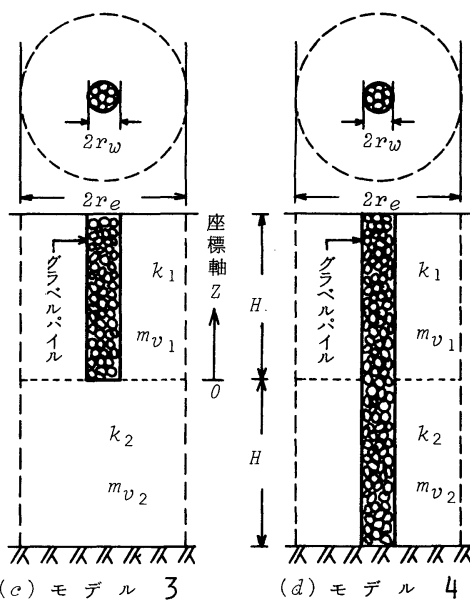

(d) モデル 4

図一1間隙水圧の発生・消散を考慮した数值解析を行った地盤 のモデル

表一1 間隙水圧の発生・消散を考虑した数值解析に用いたパラ メーターの値

\begin{tabular}{|c|c|c|c|c|c|c|c|c|}
\hline $\begin{array}{l}\text { 解析ケース } \\
\text { ハララメータ }\end{array}$ & 1 & 2 & 3 & 4 & 5 & 6 & 7 & 8 \\
\hline $\mathrm{m}_{\mathrm{v}_{2}}$ & \multicolumn{8}{|c|}{$4.082 \times 10^{-4}\left(1 / \mathrm{kP}_{\mathrm{a}}\right)$} \\
\hline $\mathrm{k}_{2}$ & \multicolumn{8}{|c|}{$4.0 \times 10^{-4}(\mathrm{~m} / \mathrm{sec})$} \\
\hline$\left(\mathrm{N}_{\mathrm{eq}} / \mathrm{N}_{\ell}\right)_{1}$ & \multicolumn{8}{|c|}{0} \\
\hline$t_{d}$ & \multicolumn{8}{|c|}{10 (秒) } \\
\hline $\mathrm{m}_{\mathrm{v}_{1}} / \mathrm{m}_{\mathrm{v} 2}$ & 1 & 0.1 & 1 & 0.1 & 1 & 0.1 & 1 & 0.1 \\
\hline $\mathrm{k}_{1} / \mathrm{k}_{2}$ & 1 & 1 & 1 & 1 & 0.1 & 0.1 & 0.1 & 0.1 \\
\hline$\left(\mathrm{N}_{\mathrm{eq}} / \mathrm{N}_{\mathrm{l}}\right)_{2}$ & 2 & 2 & 6 & 6 & 2 & 2 & 6 & 6 \\
\hline
\end{tabular}



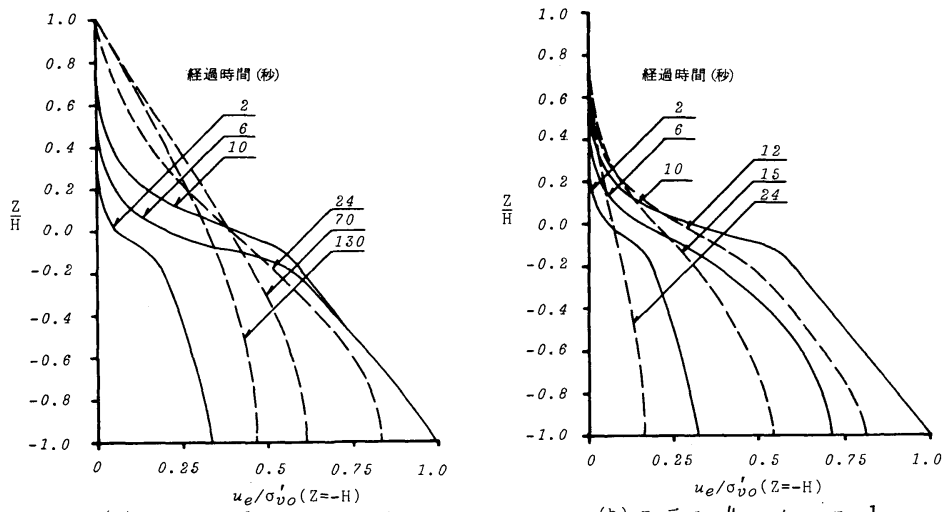

図一2 改良地盤および非改良地盤内の過剩間隙水圧の経時变化

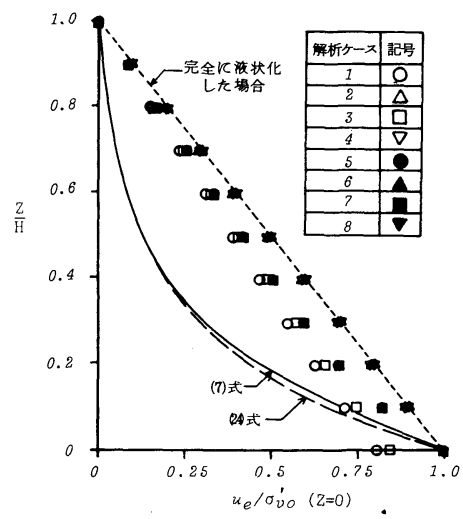

(a) $€ \vec{\gamma} n 1$

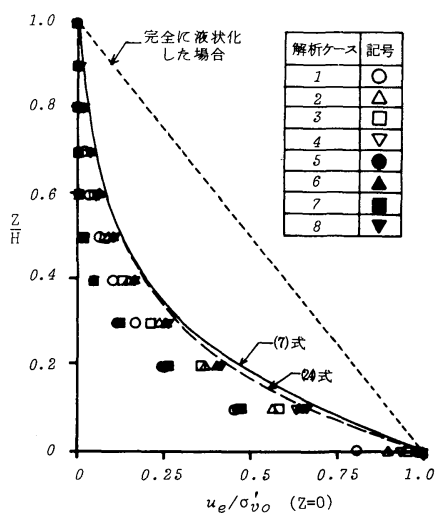

(c) $₹ \bar{T} \pi 3$
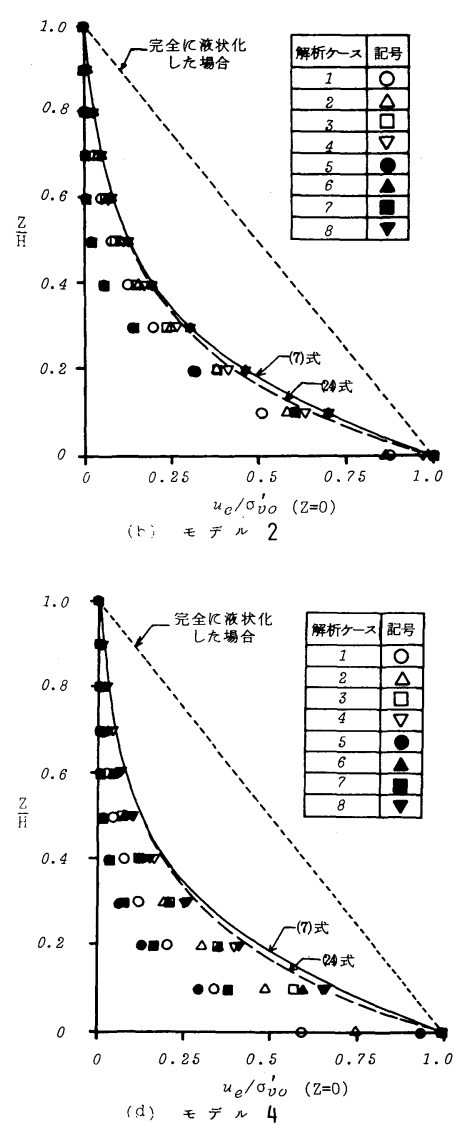

(d) モ

\section{図一3 上部砂雷内で上昇する過剩間隙水圧の時間的な最大檤の深度方向分布}

対して, 改良地盤の上部砂層で過剩間隙水圧の時間的な 最大值は，比較的小さい，このことは，グラベルパイル により，上部砂層の二次液状化が防止されていることを 示している. モデル 1 モデル 4 の各解析ケースについ て, 上部砂層の各点における過剩間隙水圧の時間的な最 大值をプロットしたものが図一3である. 図一3（a ） と図一3（b)，（c），（d）を比較 すれば,これからもグラベルパイル に二次液状化防止効果があることが わかる。

吉見ら ${ }^{5)}$ は, 非改良地盤の下部砂 層の液状化が上部砂層の安定性に及 ぼす影響について，数值解析的な検 討を行っている. そして，上部砂層 の透水性が小さいほど, 上部砂層の 圧縮性が小さいほど, 上部砂層内で 高まる過剩間隙水圧の值が大きいと 結論している.グラベルパイルを設 置した改良地盤の場合にはゼうであ ろうか. モデル 1 モデル 4 の計算 結果について吟味してゆくことにす る. 各モデルのどのケースについて も上部砂層の体積圧縮係数 $\left(m_{v 1}\right)$ が小さいほど上部砂層における間隙 水圧の時間的な最大值はより大きく なっている.この点に関しては, 非 改良地盤に関する吉見らの結果と一 致している. それに対して, 各モデ ルとも上部砂層の透水係数 $\left(k_{1}\right)$ が 小さいほざ, 上部砂層における間隙 水圧の時間的な最大值が必ず大きく なっているというわけではない。こ の点が, 非改良地盤の場合と異なる 点である.この点に関して, 個々の 解析ケースの結果についてその理由 を述べることは難しいが, 定性的に は次のような説明が成り立つと考え られる. 上部砂層の透水係数が比較 的小さい場合には, 上部砂層内の水 圧の消散速度が小さいため, 水圧の 值が大きくなりやすいという一面が ある. しかし, 上部砂層の透水係数 が小さいことは, 見方を変えると下 部砂層内の水圧が上部砂層内に伝播 するのに時間がかかるということで ある.このことは, 改良地盤の場合 のように地表面以外にも排水面が存 在する場合には, 上部砂層内の水圧の值を小さくする要 因になり得ると考えられる.

本章で行った数值シミュレーションにより,グラベル パイルの二次液状化防止効果が明らかになった．以下の 章では, この効果を定量的に評価することを目的として 実験, 解析を行っている. 


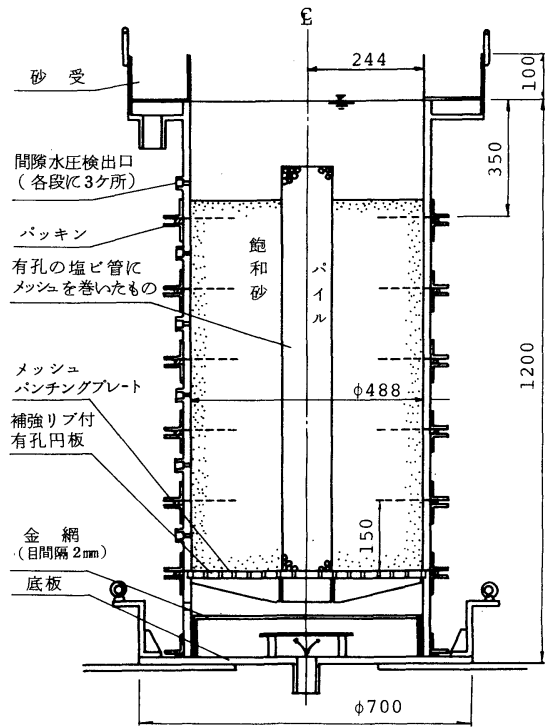

図一4＼cjkstart実験に用いた土槽の断面図

\section{3. 改良地盤および非改良地盤に対する上向き 定常透水試験}

二次液状化に対するグラベルパイルの改良効果を調ベ るために改良地盤および非改良地盤に対する上向き定常 透水試験を実施した．実験は，地震時に液状化した深部 から上向き浸透を受ける地表面近くの非液状化層を模擬 する目的で行ったものである.

以下に実験装置, 実験方法, 実験結果の概要について 説明する。

\section{（1）実験装置および測定装置等}

模型地盤を作成した土槽は, 内径 $488 \mathrm{~mm}$, 高さ $1200 \mathrm{~mm}$ の塩化ビニール製の円筒である．装置本体の 縦断面図を図一4 亿示す.

改良地盤は, 土槽の中心に設置したグラベルパイルと 水中落下法により作成したパイル周辺の飽和砂地盤より 成る．グラベルパイルとしては，理想的な条件を満たす ことの容易さを考えて, 側面に無数の穴をあけた塩化ビ ニール製のパイプの外側に周囲の砂の平均粒径よりやや 小さな目間隔のメッシュを巻きつけたものを用いた（本 論文では，以降この有孔パイプをグラベルパイルまたは 単にパイルとよぶことがある)，ただし，土槽の底面に 接したパイルの端部は，塩化ビニール製の板でふさがれ 不透水面となっており, 側面には底面より幅 $5 \mathrm{~cm}$ にわ たり,ガムテープが巻きつけられ不透水帯となっている. つまり，この実験は, 直接的には図一1のモデル 2 の上 部砂層を模擬して行ったことになる．また，パイルの中 には透水試験のときにパイルが浮き上がらないように金 属性のおもりを入れてある。 また，土槽の底面は，有孔

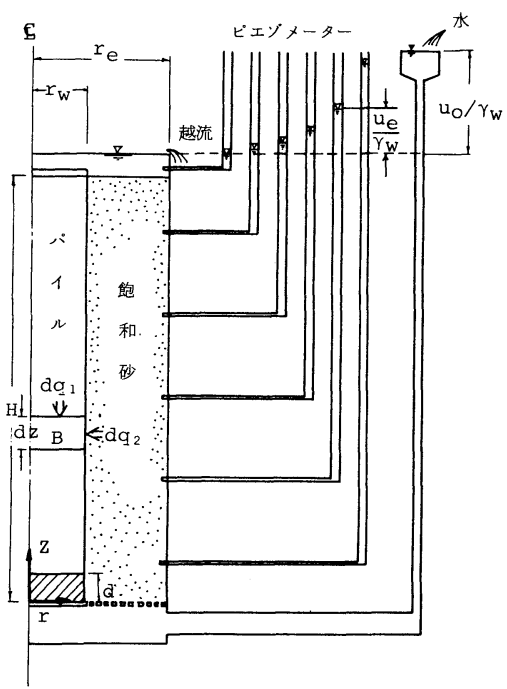

図一5上向き定常透水試験の説明図

金属板の上に砂の平均粒径よりもやや小さな目間隔の メッシュを置いたものである. 图一5に示すように水面 の高さを一定に保った水槽により砂層底部に浸透水圧を 加えることにより上向き定常透水試験を実施した．実験 装置本体は高さ方向に 6 段に分離することができる．そ の各段に 3 か所ずつある間隙水圧検出口より挿入したシ ンフレックスチューブおよびそれにつながるスタンドパ イプよりなるピエゾメーターと半導体タイプの間隙水圧 計 (TOYODA 拡散形半導体小型圧力変換器 PD 241 (容 量 $29.4(\mathrm{kPa})$ または $49.0(\mathrm{kPa}))$ により透水試験時 の地盤内の過剩静水圧を測定した. 実験に使用した砂は 豊浦標準砂 $\left(G_{s}=2.65, e_{\max }=0.976, e_{\min }=0.612\right)$ である.

\section{（2）実験方法}

モデル地盤の作成は，実験装置本体の上方に設置した 多段ふるい式モデル地盤作成装置により，あらかじめ水 を満たした実験装置本体内へ砂を自由落下させて行っ た. モデル地盤作成時の相対密度は 10２0（\%）程度 であった. モデル地盤作成後, 架台に数回〜数百回の打

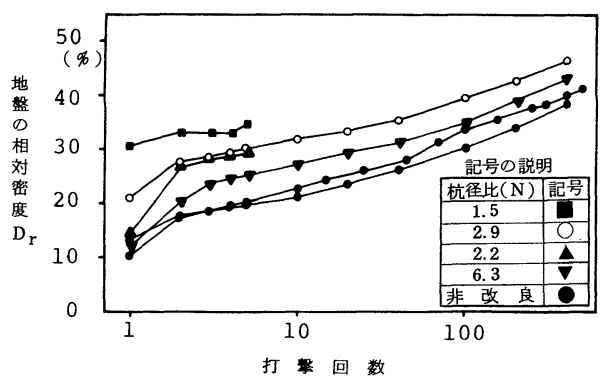

図一 6 打撃回数とモデル地盤の相対密度の関係 
撃を加えることによって密度を変化させた．打撃と打撃 の間に透水試験を行うことにより，さまざまな密度に対 する透水特性を調べた. 打撃回数と地盤の相対密度の関 係を図一6に示す.

\section{（3）実験結果の概要}

本研究において実施した実験ケースを表一2に示す.

透水試験を行った際の改良地盤および非改良地盤内の 過剩静水王分布を図一7に示す.ただし, 図中の過剩静 水圧の值は, 砂層底部の测定値によって割り算したもの を示している. 非改良地盤では当然ながら底部より地表 面に向かって直線的に減少しているのに対して, 改良地 盤では非改良地盤の場合よりも急激に減少している。し たがって, 砂層底部に大きさの等しい浸透圧を加えた改 良地盤と非改良地盤を比較した場合には，等しい深度に

\section{表一2 本研究において行った実験ケース}

\begin{tabular}{|c|c|}
\hline 杭径比 $(\mathrm{N})$ & 実 験 の内 容 \\
\hline 非 改 良 & 透一打一透一打 \\
\hline 非 改 良 & 透一打一透一打 \\
\hline 2.9 & 透一打一透一打一透 \\
\hline 6.3 & 透一打一透一打 \\
\hline 10.0 & 透一打一透一打 \\
\hline 4.2 & 打一打一打一透一打 - 打一透 \\
\hline 2.2 & 打一打一打一打 - 打 - 透 \\
\hline 1.5 & 打一打一打一打一打一透 \\
\hline $\begin{array}{c}\text { 非 改 良 } \\
2.9\end{array}$ & $\begin{array}{l}\text { 打 } 500 \text { 回, 最後に透水試験を行なら。 } \\
\text { 打慗 } 400 \text { 回, 最後に透水試験を行なら。 }\end{array}$ \\
\hline 6.3 & 打軎 400 回，最後に透水試験を行なら。 \\
\hline 非改 良 & $\begin{array}{l}\text { 打 } 400 \text { 回, 透水試験は } 1,2,3,4,5,10,20,40,100, \\
200,400 \text { 回打慗後にそれぞれ行なっている。 }\end{array}$ \\
\hline
\end{tabular}

「透」……透水試験，「打」又は「打」……打银による締固め

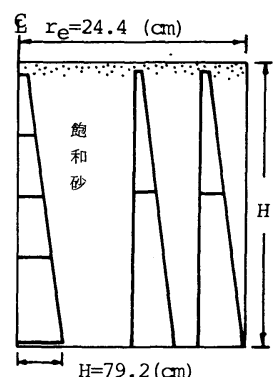

(a) 非改良地盤

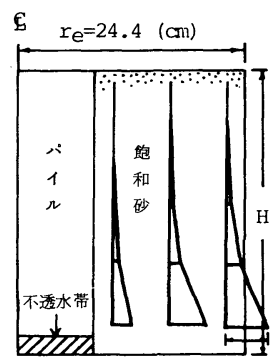

$\mathrm{H}=74.0(\mathrm{~cm})$

(c) 改良地盤 $(N=2.9)$

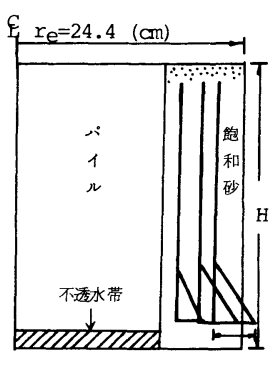

$\mathrm{H}=73.5$ (cm)

（b）改良地盤（ $N=1.5 ）$

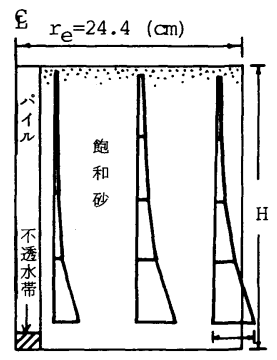

$\mathrm{H}=79.5(\mathrm{~cm})$
おける有効応力は改良地盤の方が大きいことになる.こ のことは, 改良地盤の上向き浸透に対する安定性が非改 良地盤よりも高いことを意味している.

\section{4. 上向き定常透水試験の解析}

本章では, 本研究で行った上向き定常透水試験の解析 を行い㬰験結果と比較検討する.

\section{（1）基本方程式とその解の誘道}

図一 5 に示すように座標系を定めると定常透水の基本 方程式（連続の方程式）は次式で表わされる.

$$
k_{r}\left(\frac{1}{r} \frac{\partial u}{\partial r}+\frac{\partial^{2} u}{\partial r^{2}}\right)+k_{z} \frac{\partial^{2} u}{\partial z^{2}}=0
$$

ここで, $k_{r}, k_{z}$ は, それぞれ水平方向, 鉛直方向透水 係数である. 境界条件は次のとおりである.

$$
\begin{aligned}
& u=0 \quad\left(z=H, \quad r_{w}<r<r_{e}\right) \\
& (\partial u / \partial r)_{r=r_{w}}=0 \quad\left(0<z<d, \quad r=r_{w}\right) \\
& u=0 \quad\left(d<z<H, \quad r=r_{w}\right) \\
& u=u_{0} \quad\left(z=0, \quad r_{w}<r<r_{e}\right) \\
& (\partial u / \partial r)_{r=r_{e}}=0
\end{aligned}
$$

ここに，dは不透水帯 (ガムテープを巻きつけた部分) の幅である. $(3 \cdot a) ，(3 \cdot b)$ をともに境界条件として 解を得ることは困難であるので次の条件に対する解を得 た.

$$
u=0 \quad\left(0<z<H, \quad r=r_{w}\right)
$$

式（6）を境界条件として用いることは，不透水帯の 存在を無視することを意味している.

式（1）の解は，次式で表わされる.

$$
\frac{u}{u_{0}}=\sum_{m=1}^{\infty} C_{m} D_{0}\left(l_{m} \frac{r}{r_{e}}\right) \frac{\sin h\left\{l_{m} K(1-z / H)\right\}}{\sin h\left(l_{m} K\right)}
$$

ただし，

$$
\begin{aligned}
& D_{i}(s)=J_{i}(s)-\frac{J_{1}\left(l_{m}\right)}{Y_{1}\left(l_{m}\right)} Y_{i}(s), \quad(i=0,1) \\
& C_{m}=\frac{-\frac{2}{N l_{m}} D_{1}\left(\frac{l_{m}}{N}\right)}{\left\{D_{0}^{2}\left(l_{m}\right)-\frac{1}{N^{2}} D_{1}^{2}\left(\frac{l_{m}}{N}\right)\right\}} \cdots \cdots \cdots \cdots . . .
\end{aligned}
$$

であり, $l_{m}\left(m=1,2, \cdots, 0<l_{1}<l_{2}<\cdots\right)$ は, 次式の解 である。

$$
D_{0}\left(l_{m} / N\right)=0
$$

\section{（2）実験結果と解析結果との比較}

a) 改良地盤内の過剩間隙水圧に関して

式 (7) において, 透水係数は等方的 $\left(k_{r}=k_{z}\right)$ と 仮定して, $u_{e}\left(r=r_{e}\right.$ における $u$ の値）に関して実験結 果亡解析結果を比較したものが図一8である. 実験結果 と解析結果は良好に一致している. 中心軸を含む縦断面 内における過剩静水王分布に関して実験結果と解析結果 を比較したものが図一 9 である. 砂層底部付近の 3 つの 


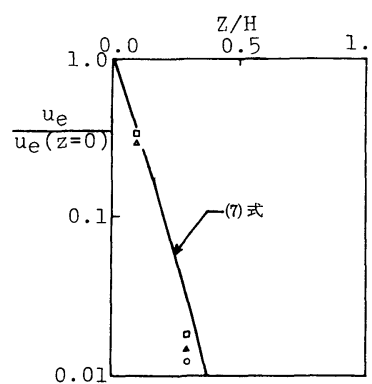

(a) 改良地盤 $(\mathrm{N}=1.5)$

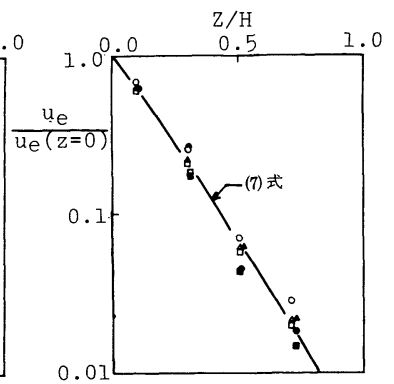

(b) 改良地盤 $(\mathrm{N}=2.9)$

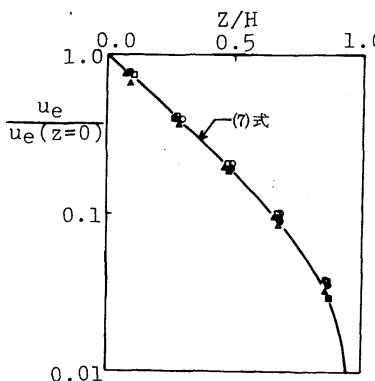

(c) 改良地盤 $(\mathrm{N}=10.0)$
記 号 の 説 明

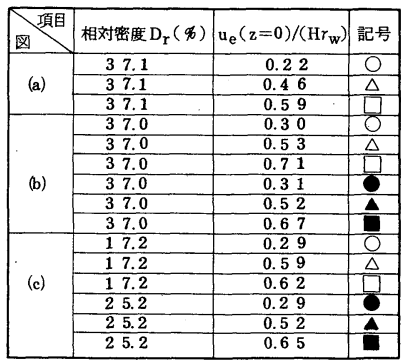

図一8 解析と実験によって求めた改良地盤内の過剩静水圧の深 さ方向の分布

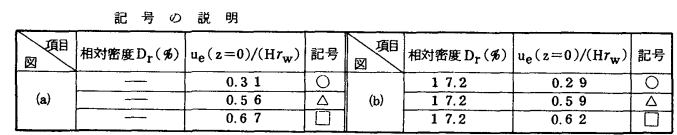

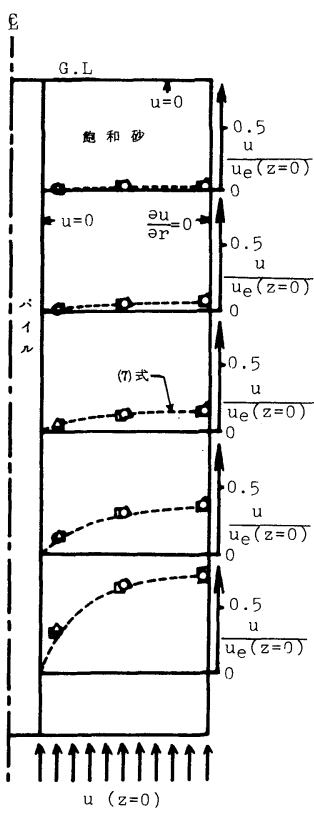

(a) 改良地盤 $(N=6.3)$

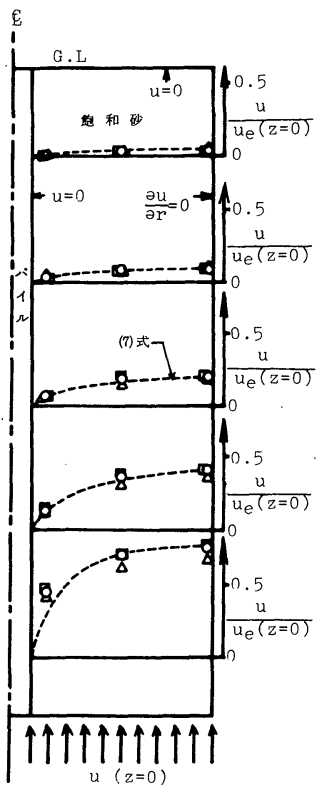

(b) 改良地盤 $(N=10.0)$
図一9 解析と実験によって求めた改良地盤内の過剩静水圧分布 の比較
測定点で測定された過剩静水圧のうち，最もパ イルに近いものの值は, 計算値よりもいくぶん 大きな值となっている。これは，パイルの下部 に幅 $5 \mathrm{~cm}$ にわたり巻きつけた不透水帯による 影響である.その他の測定点における測定值は， 計算値と良好に一致している。

式（７）による計算結果は, 図一3(b)，(c), （d）中にも実線で示されている．下部砂層か らの上向き浸透の結果上部砂層中で上昇する過 剩静水圧の值は, 式（7）によって計算された 値を上回っていない。すすなわち，下部砂層から の上向き浸透により上部砂層で上昇する過剩静 水圧の上限值は, 式 ( 7 ) で与えられているこ とがわかる。

\section{5. 簡便解の誘導}

本章では，バロン（Barron, R.A）の圧密理 論7におおる等ひずみ条件の解を求めるのと似 通った方法により式 $(7)$ の簡便な近似解を誘 導する. 浸透流の基本方程式として示した式

（1）は，実は地盤内の微小要素に出入りする 流量に関する連続の方程式であった。ここでは 見方を変えて図一10 中に示される要素 Aに出入りする 流量に関して連続方程式を考える。

$z$ 軸に垂直な面を通って要素内に流入する水の量 $\Delta Q_{z}$ は次式で近似的に表わされる。

$$
\Delta Q_{z}=\pi\left(r_{e}^{2}-r^{2}\right) \frac{\partial^{2} \bar{u}}{\partial z^{2}} k_{z} \Delta z \Delta t
$$

ただし, $\bar{u}$ は, $r=r \sim r_{e}$ における過剩静水圧の空間的 な平均值である.すなわち,

$$
\bar{u}=\frac{1}{\pi\left(r_{e}^{2}-r^{2}\right)} \int_{r}^{r_{e}} u(r, z) 2 \pi r d r
$$

である.

一方, $r$ 軸に垂直な面を通って要素内に流入する水 の量 $\Delta Q_{r}$ は次式で表わされる.

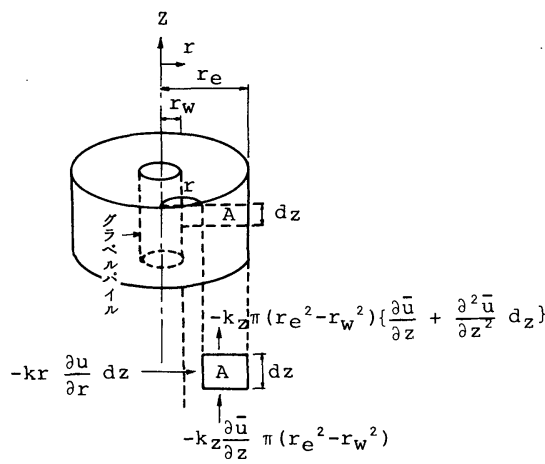

図一10 砂層内の要素 A に関する水の出入り 


$$
\Delta Q_{r}=-(2 \pi r \Delta z) \frac{\partial u}{\partial r} k_{r} \Delta t
$$

要素内に出入りする水量の連続性を考えれば次式が成 立する.

$$
\Delta Q_{z}+\Delta Q_{r}=0
$$

式（11）および式（13）を式（14）に代入すれば次式 が得られる.

$$
\frac{\partial u}{\partial r}=\left(\frac{1}{2} \frac{k_{z}}{k_{r}}\right)\left(\frac{r_{e}^{2}}{r}-r\right) \frac{\partial^{2} \bar{u}}{\partial z^{2}}
$$

式（7）において，K が十分大きくかつ $z / H$ が小さ ければ, 第 1 項の影響が第 2 項以降の項の影響に比べて 大きくなるため近似的には次式で表わされる.

$$
\frac{u}{u_{0}}=C_{1} D_{0}\left(l_{1} \frac{r}{r_{e}}\right)
$$

図一11中に式（16）で表わされる曲線を示す.また, 半径方向の過剩静水圧分布が式（16）で表わされるとき の $\bar{u}$ の $r$ に対する変化を図一12 に示す. $r$ の変化に伴 う $\bar{u}$ の変化は小さいとはいえない.このように $\bar{u}$ の值 は $r$ に対して必ずしも一定ではないが，これを常に一 定であると仮定して式 (15) を解くことにする. 式 (15) の解は, 式（6）を考慮すると次式で与えられる.

$$
u=\frac{1}{2} \frac{k_{z}}{k_{r}}\left(r_{e}^{2} \ln \frac{r}{r_{w}}-\frac{r^{2}-r_{w}^{2}}{2}\right)\left(\frac{\partial^{2} \bar{u}}{\partial z^{2}}\right) .
$$

式（17）において $r=r_{e}$ とした場合には， $u=u_{e}, \bar{u}$ $=u_{e}, r_{e} / r_{w}=N$ などにより次式が得られる.

$u_{e}=\left(\frac{1}{2} \frac{k_{z}}{k_{r}} r_{e}^{2}\right)\left(\ln N-\frac{N^{2}-1}{2 N^{2}}\right) \frac{\partial^{2} u_{e}}{\partial z^{2}}$

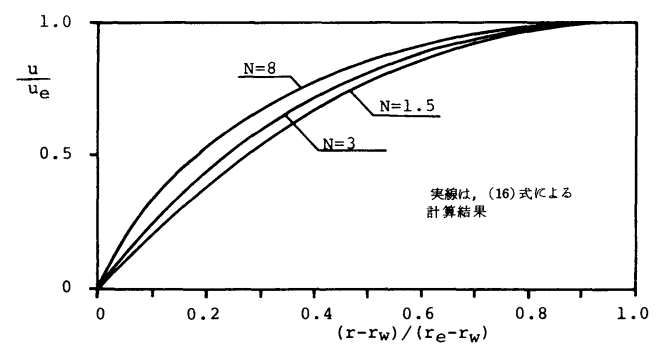

図一11過剩静水圧の半径方向分布の計算値

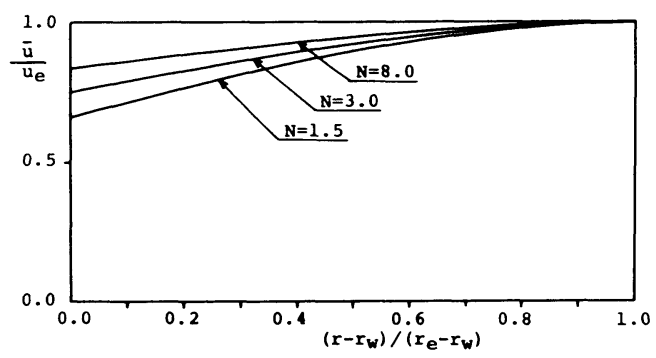

図一12 $r$ の值の变化に伴う $\bar{u}$ の値の变化
式（18）をさらに書き直すと次式が得られる.

$\frac{\partial^{2} u_{e}^{\prime}}{\partial z^{\prime 2}}=\{K f(N)\}^{2} u_{e}^{\prime}$

ここに,

$$
u_{e}^{\prime}=u_{e} / u_{e}(z=0)
$$

$z^{\prime}=z / H$

$K=\sqrt{\frac{k_{r}}{k_{z}}} \frac{H}{r_{e}}$

$$
f(N)=\sqrt{\frac{2}{\left(\ln N-\frac{N^{2}-1}{2 N^{2}}\right)}}
$$

$z^{\prime}=0$ で $u_{e}^{\prime}=1$ であることを考慮して式 (19) を解け ば次の解が得られる.

$$
u_{e}^{\prime}=\frac{\sin h\left\{f(N) K\left(1-z^{\prime}\right)\right\}}{\sin h(f(N) K)}
$$

図一8 中の式（7）による計算結果を含むさまざまな 条件に対する式（7）による計算結果と式（24）による 計算結果を比較したものが図一13である. $r=r_{e}$ にお ける過㮃静水圧 $\left(u_{e}\right)$ の値は, 式 $(7)$ を用いなくて も比較的簡易な式 (24) を用いれば, 工学的には十分な 精度が得られることがわかる.

式（24）による計算結果は, 図一3 ( b ), (c), (d ) 中にも破線で示されている. 式（7）による計算結果と ほぼ同じ值となっている.すなわち, 下部砂層からの上 向き浸透により上部砂層で上昇する過剩静水圧の上限值 は，ほぼ式（24）により与えられる.

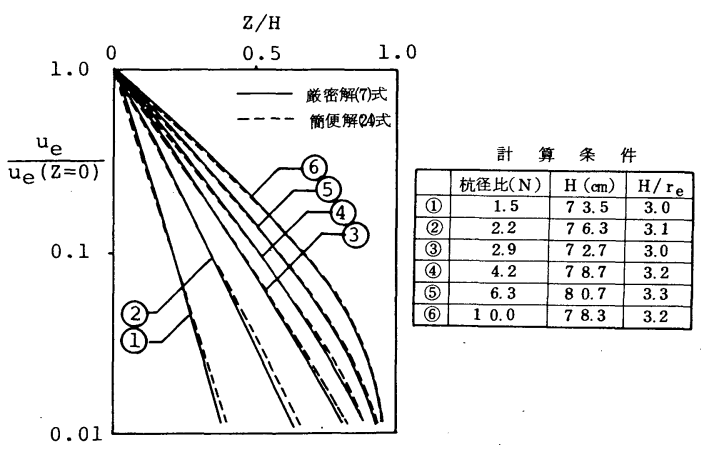

図一13誉密解と簡便解の比較

\section{6. グラベルパイルの二次液状化防止効果が地 盤の支持力に与える効果}

すでに他の研究者によって提案され，実用化されてい る水平地盤の一次液状化の判定方法を用いれば，地震時 に非改良地盤内のある深度にある地層が液状化するか否 かを予測することができる．地盤の大部分が液状化する 場合には, その地盤中の構造物およびその地盤に支持さ れる構造物に大きな被害が生じることは明らかである. 
しかし，地盤の一部分だけが液状化した場合には，大き な被害が生じるとは限らない，地盤の一部分だけが液状 化すると判定された場合，何らかの対策をすべきか否か についての明確な判断基準はなく，技術者自身の判断に 任されているのが現状である。このことは，二次液状化 防止のためにグラベルパイルを設計する際に，明確な改 良目標が設定できないということを意味している，そこ で, 本章では, 地表面上の構造物の安定に及ぼすグラべ ルパイルの二次液状化防止効果を定量的に評価するため に上部砂層内の過剩静水圧の大きさを考慮した支持力解 析を行った。なお，解析にあたっては簡単のために以下 のような仮定をしている.

(1) 上部砂層の液状化安全率は十分大きいとする，そ れゆえ，上部砂層内で上昇する過剩静水圧は地震時 の繰り返しせん断によるものではなく，液状化した 下部砂層からの上向き浸透によるものとする.

（2）上部砂層内の過剩静水圧分布は，水平方向に一様 であるとし，鉛直方向には式（24）で表わされると する.

(3) グラベルパイルの存在が, 支持力に与えるパイル としての効果は無視し，一様な摩擦角 $\left(\phi^{\prime}\right)$ と水中 重量 $\left(\gamma^{\prime}\right)$ を有する砂地盤であるとする.

(4) 地下水面の位置は, 地表面と一致している.

(5) 下部砂層の過剩間隙水圧が上昇し，軟弱化した後 の上部砂層および構造物の安定を考えているので, 上部砂層および上部構造物に加わる水平地震力は小 さいとして無視する.

(6) 基礎としては，最も基本的な根入れのない帯基礎 を考える.

二次液状化による地盤の破壊形式としては，次の $2 \supset$ が考えられる。

亿）上部砂層の厚さ $\left(H_{l}\right)$ の基礎幅（B）に対する 比 $\left(H_{l} / B\right)$ が比較的大きいため, 破壊が上部砂層 内でのみ起こる場合.

口）上部砂層の厚さ $\left(H_{l}\right)$ の基礎幅（B）に対する 比 $\left(H_{l} / B\right)$ が比較的小さいために, 破壊が上部砂 層のみならず下部砂層にも及ぶ場合.

イ）の場合には，上部砂層が締まっている限り，従来 の支持力理論に過剩間隙水圧の効果を加えることにより 支持力評価が可能である. それに対して, 口)の場合には, 2 層地盤の支持力問題となるが，こうした場合の破壊の パターンは不明であり，支持力を算定することはできな い．本論文では，イ）の場合を対象として支持力を検討 することにする，イ）の場合の支持力を求めるには，過 剩間隙水圧を考慮して Kötter 方程式を解く方法が一番 厳密な解が得られる方法であろう ${ }^{8)}$. しかし，この方法 で支持力を求めようとすれば非常に繁雑な計算が必要に

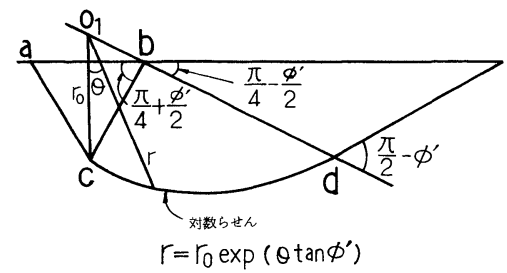

図一14 対数らせんによる支持力の計算

なるので，ここでは比較的簡便な方法を用いることにす る.

地盤内の過剩間隙水圧を考慮した支持力の計算方法之 しては, 八木' ${ }^{9)}$ が行ったものがある.八木 ${ }^{99}$ は, 基礎の 端部に極のある対数らせんに沿って, 塑性つり合い方程 式を積分することにより, 支持力解析を行っている.し かし, この方法の場合, 地盤内の過剩間隙水圧の分布に かかわらず積分経路は一定であるので, 最も外側の対数 らせんの外側の地盤条件は支持力には影響しないことに なる.

本章で解析しようとしているのは, 深度方向に過剩間 隙水圧が増加する地盤であり，深いすべり線ほど大きな 支持力を与えるとは限らない. そこで, ここではテル ツァーギの支持力計算方法に基づき，いろいろなすべり 線による支持力の最小値を求めることにする.

図一14 は，その計算方法を説明したものである. く さび底角 $\angle \mathrm{abc}$ は, $\phi^{\prime} / 2+\pi / 4$ とした。 また, 線分 $\mathrm{cb}$ 上での鉛直土圧は, 点 $\mathrm{c}$ で最大值, 点 $\mathrm{b} て ゙ 0$ (ゼロ) と なる三角形分布とした．このようにすることにより，地 盤内に過㮃間隙水圧が存在しない場合の支持力の計算値 は，テルツァーギによるものと一致させた．また，対数 らせんの極 $\mathrm{O}_{1}$ を線分 bd またはその延長上を移動させ 各位置での支持力を計算し，その最小値をもって地盤の 支持力とした.

このようにして得られた支持力強度 $\left(q_{u}\right)$ を次のよ うにして表わす。

地盤内に過剩静水圧がない場合

$$
q_{u}=\frac{B \gamma^{\prime}}{2} N_{\gamma}
$$

地盤内に過㮃静水圧がある場合

$$
q_{u}^{*}=\frac{B \gamma^{\prime}}{2} N_{\gamma}^{*}
$$

$\phi^{\prime}=40$ (度) のもとに $N_{\gamma}^{*} / N_{\gamma}$ を計算し図にしたもの が図一15である．対数らせんの極は，対数らせんが下 部砂層を通過しない範囲で移動させた. 図一15中の白 丸は, 上部砂層と下部砂層の境界面に接する対数らせん が支持力の極小值を与える場合に対応している.すすな ち，白丸印で表わされた場合は，口）の破壊形式で破壊 する可能性の高いものであるということができる．図一 


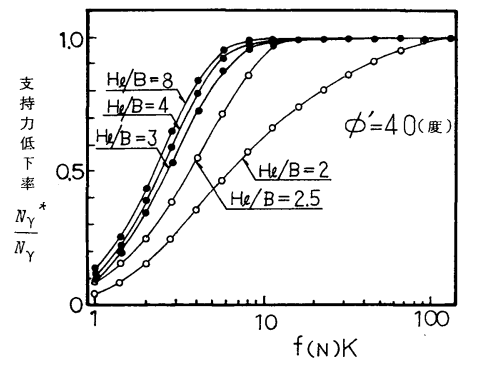

図一15 二次液状化による改良地盤の支持力低下

15 を用いれば，グラベルパイルの二次液状化防止効果 を支持力の面から評価することが一応は可能である.し かし，支持力を計算するに際して簡単のためにいくつか の仮定を導入したため, 支持力計算自体を実に精密に行 うことができる余地がある，さらに，支持力計算自体を 精密にしたとしても, 実際問題に支持力解析の結果をそ のまま適用してよいかどうか判断するには，実験的な裏 付けが必要であろう.

\section{7. ま と}

以下に，本論文により得られた主な結論を記す。

（1）数值解析を行うことにより，グラベルパイルに 二次液状化防止効果があることを明らかにした。

（2）グラベルパイルを設置した改良地盤に対して上 向き透水試験を実施し, 上向き透水に対するグラベルパ イルの効果を実証した. さらに, 基本方程式を解くこと により, 解析解を得て実験結果と比較し，よく一致する ことを確かめた。

（３）上向き透水解析の結果得られる上部砂層の過剩 静水圧分布は, 下部砂層が液状化した場合, 上部砂層で 上昇する過剩静水圧の上限值を与えていることがわかっ た.

（4）上向き透水を受ける上部砂層内の過剩静水圧を 簡便に表現できる式を導いた。

（5）上向き透水を受ける上部改良地盤内の過剩静水 圧を考慮した支持力解析を行い, グラベルパイルの二次 液状化防止効果を支持力の面から評価した。

謝辞：本研究の計画段階において, 東京大学 石 原研而教授のご指導を賜わりました。ここに厚くお礼申 し上げます．また，本研究における実験は，当時の日本 大学卒論生 高野 仁君 (現・牛久町役場) の助力を得 ました、末筆ながらここに梁く感謝致します。

\section{本論文で使用した主な記号の説明}

$$
\begin{aligned}
& r_{w}: \text { グラベルパイルの半径 } \\
& r_{e} \text { : 有効円の半径 }{ }^{* 1}
\end{aligned}
$$

$N$ : 杭径比 $\left(r_{e} / r_{w}\right)$

$H:$ 上部砂層の厚さ

$r:$ 改良地盤の半径方向の座標（中心で $r$ $=0)$

$t:$ 時間

$z:$ 深さ方向の座標

$u(r, z)$ : 半径方向の座標 $r$, 深さ方向の座標 $z$ における過剩静水圧の值

$u_{0}:(=u(r, 0))$

$u_{e}:\left(=u\left(r_{e}, z\right)\right)$

$u_{e}(z=0):\left(=u\left(r_{e}, 0\right)\right)$

$k_{z}, k_{r}:$ それぞれ砂の鉛直方向水平方向透水係数 $m_{v}:$ 砂の体積圧縮係数

$k_{w}:$ グラベルパイルの透水係数

$K:\left(=\sqrt{k_{r} / k_{z}} \cdot H / r_{e}\right)$

$\sigma_{v 0}^{\prime}:$ 鉛直有効土かぶり圧

$f(N):\left(=\sqrt{\frac{2}{\ln N-\frac{N^{2}-1}{2 N^{2}}}}\right)$

$N_{l}$ : 非排水条件下で液状化に要する繰り返し 回数

$N_{e q}$ : 不規則に加わるせん断応力波と等価な一 定振幅せん断応力の繰り返し回数

$t_{d}:$ 地震動の有効継続時間

$J_{0}(), J_{1}()$ : それぞれ第 0 次, 第 1 次の第 1 種ベッセ ル関数

$Y_{0}(\quad), Y_{1}()$ ：それぞれ第 0 次, 第 1 次の第 2 種ベッセ ル関数

* 1

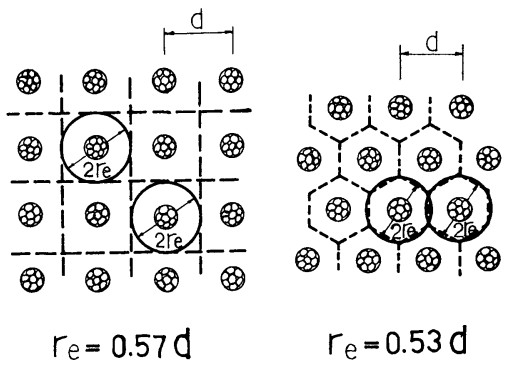

\section{参 考 文 献}

1）田中・国生・江刺・松井：グラベルパイルによる水平地 盤の液状化防止について, 土木学会論文集, No. 347/III-2, pp. 89 98, 1984.

2）石原研而: 土質動力学の基礎, 鹿島出版会, pp. 286 288, 1976.

3）吉見吉昭：砂地盤の液状化，技報堂出版，1980.

4) Seed, H. B., Martin, P. P. and Lysmer, J. : PoreWater Pressure Changes During Soil Liquefaction, J. GED, ASCE, Vol.102, No. GT 4, pp. 323 346, 1976. 
5) Yoshimi, Y. and Kuwabara, F. : Effects of Subsurface Liquefaction on the Strength of Surface Soil, Soils and Foundations, Vol.13, No.2, pp. 67 81, 1973.

6) Booker, J.R., Rahman, M.S. and Seed, H. B. : GADFLEA-A Computer Program for the Analysis of Pore Pressure Generation and Dissipation During Cyclic or Earthquake Loading, EERC 76-24, 1976.
7) Barron, R. A. : Consolidation of Fine-Grained Soils by Drain Wells, Trans, ASCE, Vol.113, pp. 718 742, 1948.

8）山口柏樹: 土質力学, 技報堂, pp. 260 280, 1969.

9）八木則男：繰り返し荷重を受けた砂の力学特性とその応 用に関する研究, 京都大学学位論文, pp. 101 106, 1974.

(1984.11.27 - 受付) 